\title{
First report of Groundnut Bud Necrosis Virus infecting Taro (Colocasia esculenta)
}

\author{
Y. Sivaprasad • B. V. Bhaskara Reddy • \\ C. V. M. Naresh Kumar • K. Raja Reddy • \\ D. V. R. Sai Gopal
}

Received: 11 August 2010 /Accepted: 17 February 2011 /Published online: 21 May 2011

(C) Australasian Plant Pathology Society Inc. 2011

\begin{abstract}
The natural occurrence of Groundnut Bud Necrosis Virus (GBNV) on Colocasia esculenta was detected by enzyme linked immunosorbent assay using an antiserum raised against GBNV and reverse transcription polymerase chain reaction using coat protein specific primers. Sequence analysis showed $93-99 \%$ and $95-99 \%$ identity at nucleotide and amino acid levels respectively with other reported GBNV isolates.
\end{abstract}

Keywords Groundnut bud necrosis virus · Taro · DAC . ELISA $\cdot$ RT $\cdot$ PCR

Taro (Colocasia esculenta) a member of the Araceae family, is a traditional root crop of the tropics grown for its edible corms and leaves, and is believed to be one of the earliest cultivated root crops in the world (Plucknett 1976; Kuruvilla and Singh 1981). Corms and leaves of taro are also accredited to have medicinal importance and are used to reduce tuberculosis, ulcers, pulmonary congestion and fungal infections (Misra and Sriram, 2002). Taro is the second most important staple crop in Papua New Guinea; 14th in the world (Singh et al. 2006). The food and agricultural organization estimates that 9.1 million metric tons of corms are produced annually over an area of 2 million ha, but this largely under estimates its production as

Y. Sivaprasad $\cdot$ B. V. B. Reddy $(\square) \cdot$ K. R. Reddy

Department of Plant Pathology, Regional Agricultural Research

Station, Acharya N.G. Ranga Agricultural University,

Tirupati 517502, Andhra Pradesh, India

e-mail: bvbreddy68@gmail.com

C. V. M. N. Kumar • D. V. R. S. Gopal

Department of Virology, SVU College of Sciences,

Sri Venkateswara University,

Tirupati 517502, Andhra Pradesh, India few countries keep reliable figures (Mishra et al. 2009). To date five viruses have been reported to infect taro [Dasheen mosaic virus (DSMV), Taro Bacilliform virus (TaBV), Colocasia bobone disease virus (CBDV), Taro vein chlorosis virus (TaVcv) and Taro reovirus (TaRV)]. Tospoviruses are among the most damaging and economically important group of plant viruses causing significant crop losses in wide range of ornamental and food crops in many regions of the world (Mumford et al. 1996). Groundnut Bud Necrosis Virus (GBNV) a member of the genus Tospovirus, family Bunyaviridae consists of enveloped, quasi spherical particles, approximately $80-120 \mathrm{~nm}$ in diameter. GBNV has a wide host range (Groundnut, Tomato, Chilies, Potato, Peas, Sunflower, Green gram, Black gram, Cowpea, Cotton, Soybean, Field bean, Carrot, Brinjal, Ornamentals
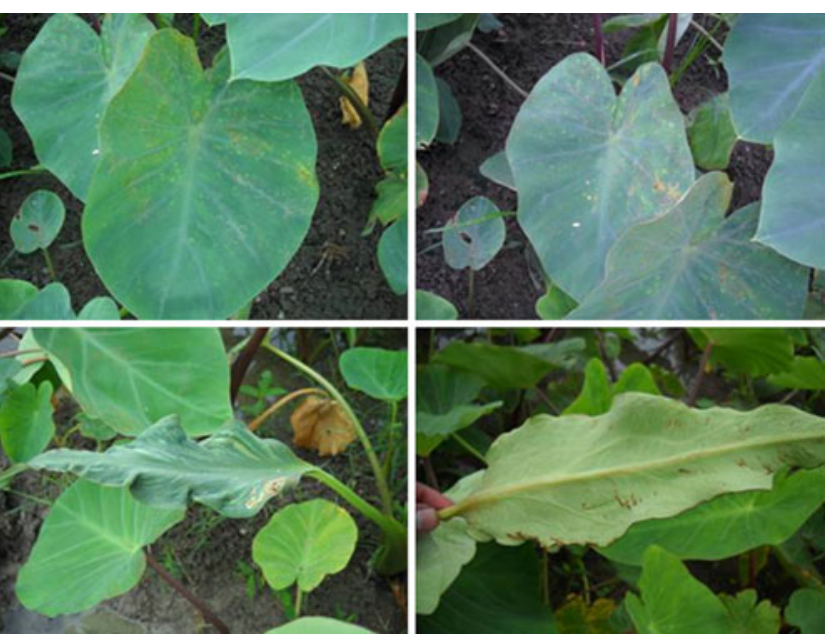

Fig. 1 Symptoms associated with natural occurrence of Groundnut Bud Necrosis virus on colocasia: mosaic, chlorotic spotting and necrotic flecking of leaves 


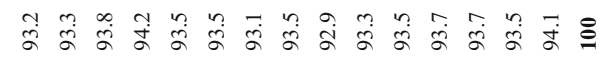

苍

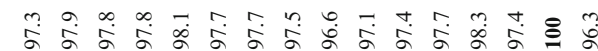

ì

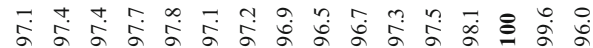

萬

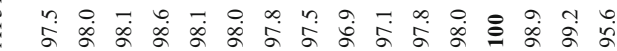

腒

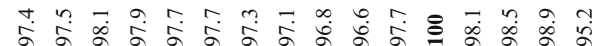

$\overrightarrow{\substack{\infty \\ \stackrel{n}{n}}}$

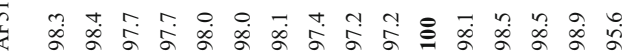

宽

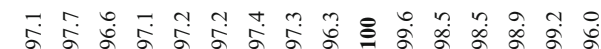

兽

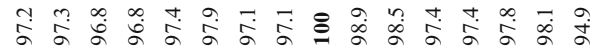

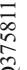

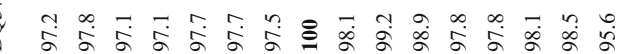

ठิ

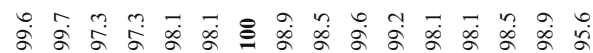

岕

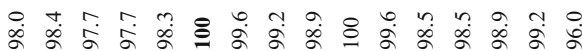

等

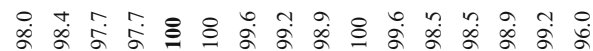

ڤे

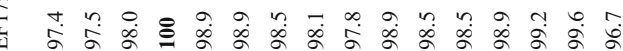

ลิ

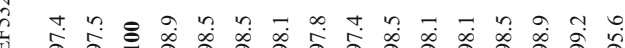

$\frac{8}{2}$

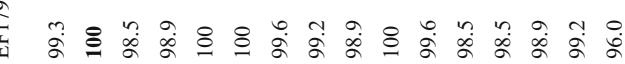

$\stackrel{10}{\infty}$

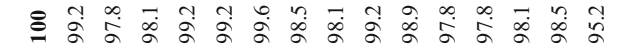

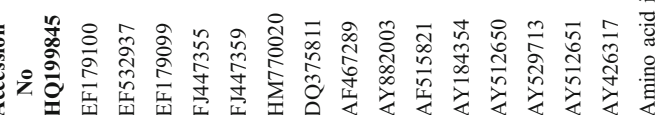

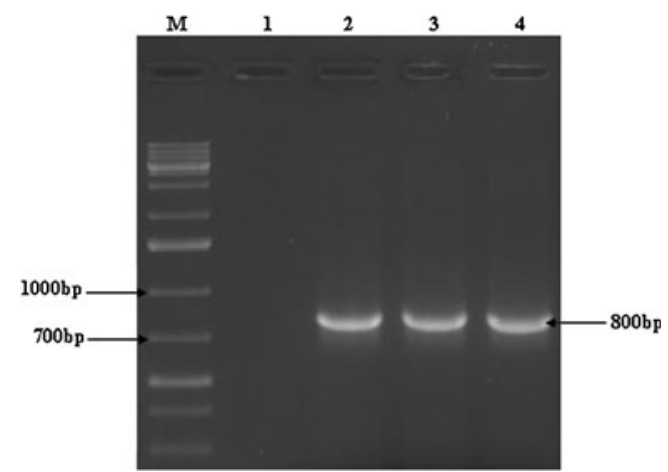

Fig. 2 Agarose gel electrophoresis of RT-PCR products. Lane M, $1 \mathrm{~Kb}$ DNA ladder. Lane 1, healthy. Lane 2,3,4, infected colocasia samples

and weeds; Vigna unguiculata, Nicotiana glutinosa, Petunia hybrida, Vinca rosea and Trapaeolum majus) (Reddy 1991).

Host range studies for GBNV and TSV have been carried out in our laboratory for the past 4 years. During one survey in 2010 we found GBNV suspected infection in colocasia fields in Nellore district of Andhra Pradesh, India. Mosaic, chlorotic spotting and necrotic flecking of leaves were observed (Fig. 1). Stunted growth was observed in infected plants. The symptomatic leaves tested positive for PBNV by DACELISA (Clark and Joseph 1984) using polyclonal antibodies. The samples were also screened for TSV and were found to be negative. RT-PCR tests of leaf tissue from diseased colocasia plants using primers specific for the nucleocapsid gene of GBNV (Satyanarayana et al. 1996) resulted in an amplicon of the expected size ( $\sim 800$ bp) (Fig. 2). The amplicon was cloned into pTZ57R/T vector (Fermentas, USA), sequenced and deposited in GenBank DNA database (Accession No. HQ199845). Sequence analysis (BioEdit v. 7.05 ) and comparison with other GBNV isolates (GenBank Accession No.EF179100, EF179099, EF532937, FJ447355, FJ447359, HM770020, DQ375811, AF467289, AY512650, AY882003, AY529713, AY512651, AF515821, AY426317, and AY184354) showed $93-99 \%$ and $95-99 \%$ identity at nucleotide and amino acid levels respectively (Table 1).

The infected colocasia crop was destroyed in the interest of national biosecurity. Considering the economic importance and global consumption of colocasia, it is important for the impact of GBNV to be studied further. To the best of our knowledge this is the first report of the natural occurrence of GBNV on colocasia.

Acknowledgment We are very grateful to Dr. P. Lava Kumar, International Institute of Tropical Agriculture Ibadan for his gift of antisera.

\section{References}

Clark MF, Joseph MB (1984) Enzyme immunosorbent assays in plant virology. In: Maaramorosch K, Koprowski H (eds) Methods in virology, vol. II. Academic, New York, pp 51-58 
Kuruvilla KM, Singh A (1981) Karyotypic and electrophoretic studies on taro and its origins. Euphytica 30:405-412

Mishra AK, Sharma K, Misra RS (2009) Purification and characterization of elicitor protein from phytophthora colocasia and basic resistance in Colocasia esculenta. Micrbiological Res 164:688693

Misra RS, Sriram S (2002) Medicinal value and export potential of tropical tuber crops. In: Govil JN, Pandey J, Shivkumar BG, Singh VK (eds) Recent progress in medicinal plants, crop improvement, production technology and commerce. SCITechPub, USA, pp 376-386

Mumford RA, Barker I, Wood KR (1996) The biology of the tospoviruses. Ann Appl Biol 128:159-183
Plucknett DL (1976) Edible aroids; alocasia, colacasia, cytosperma. In: Simmonds NW (ed) Evolution of crop plants. Longman, London, pp 10-12

Reddy DVR (1991) Groundnut viruses and virus diseases; distribution, identification and control. Rev Plant Pathol 70:665-678

Satyanarayana T, Mitchell SE, Reddy DVR, Brown S, Kresovich S, Jarret R, Naidu RA, Demski JW (1996) Peanut bud necrosis tospovirus S RNA: complete nucleotide sequence, genome organization and homology to other tospoviruses. Arch Virol 141:85-98

Singh D, Guaf J, Okpul T, Wiles G, Hunter D (2006) Taro (Colocasia esculenta) variety release recommendations for Papua New Guinea based on multilocation trials. NZ J Crop Horticultural Sci 34:163-171 